\title{
Amusium cristatum shell beds in the lower Pliocene deposits of Almería- Níjar Basin (SE Spain)
}

\author{
Julio AGUIRRE
}

Dpto. Estratigrafía y Paleontología, Facultad de Ciencias, Campus de Fuentenueva s.n. Universidad de Granada, 18002 Granada (Spain); jaguirre@ugr.es

Aguirre, J. 2017. Amusium cristatum shell beds in the lower Pliocene deposits of Almería-Níjar Basin (SE Spain). [Niveles de Amusium cristatum en depósitos del Plioceno inferior de la Cuenca de Almería-Níjar (SE España)]. Spanish Journal of Palaeontology, 32 (1), 3-16.

Manuscript received 10 October 2016

Manuscript accepted 11 January 2017

(C) Sociedad Española de Paleontología ISSN 2255-0550

\begin{abstract}
Densely packed monospecific-paucispecific Amusium cristatum-dominated shell beds are significant features in the lower Pliocene deposits of the Almería-Níjar Basin (SE Spain), embedded in distal prodelta fine-grained sand and silt. The shells in these concentrations are exceptionally well preserved: articulation is relatively high, fragmentation is low, abrasion is almost lacking, and many shells preserve the original colour pattern. These taphonomic signatures suggest in situ deposition forming autochthonous fossil assemblages, i.e. biological concentrations. Benthic foraminiferal assemblages found in the prodelta deposits indicate that they formed in mesotrophic mid-shelf settings.

The A. cristatum accumulations show similarities with recent concentrations of $A$. balloti from the Shark Bay (NW Australia). The latter species form dense populations in restricted positions of the bay from 10 to $75 \mathrm{~m}$ depth. The lowermost depth range of $A$. balloti is similar to the palaeobathymetry inferred for the A. cristatum beds. Furthermore, the shell beds studied occur in the centre of a relatively enclosed palaeobay. Apart from these coincidences, the proximate ecological causes accounting for the recent concentrations of $A$. balloti are still obscure. Thus, no straightforward actualistic comparison explains the biological origin of the A. cristatum shell beds. Based on benthic foraminiferal assemblages in the prodelta deposits, $A$. cristatum concentrations are most likely related to intermittent nutrient and food-particle supply from several deltas feeding
\end{abstract}

\section{RESUMEN}

En los depósitos del Plioceno inferior de la Cuenca de Almería-Níjar (SE de España) se encuentran niveles de densas acumulaciones monoespecíficas-pauciespecíficas dominadas por Amusium cristatum. Dichos niveles están intercalados en arenas muy finas y limos depositados en zonas distales de prodelta. Los bivalvos muestran una excelente preservación: articulación relativamente alta, baja fragmentación, abrasion prácticamente nula, y algunos de los pectínidos preservan los patrones de coloración original. Estas propiedades tafonómicas indican una preservación in situ generando asociaciones autóctonas o concentraciones biológicas. Las asociaciones de foraminíferos bentónicos encontradas en los limos de prodelta indican que los niveles de pectínidos se formaron en un ambiente mesotrófico de plataforma media. Las acumulaciones de $A$. cristatum muestran similitudes con las concentraciones actuales de A. balloti de Shark Bay (NO de Australia). Esta especie forma densas poblaciones en zonas protegidas de la bahía entre 10 y $75 \mathrm{~m}$ de profundidad. El límite batimétrico inferior de $A$. balloti es similar a la profundidad estimada para las concentraciones de $A$. cristatum. Asimismo, los niveles estudiados se encuentran en el centro de una paleobahía semicerrada. A parte de estas coincidencias, las causas ecológicas últimas que explican las concentraciones actuales de A. balloti no son del todo conocidas. Por tanto, no se pueden usar aproximaciones actualistas para interpretar los niveles de A. cristatum. Las asociaciones de foraminíferos bentónicos de los limos de 
the palaeobay. The advance of the deltas to the centre of the basin guaranteed rapid burial and the excellent preservation of the shells.

Keywords: Taphonomy, biological concentrations, Amusium balloti, Amusium pleuronectes, Abrioja delta. prodelta indican que los niveles de $A$. cristatum se formaron probablemente en relación con aportes de nutrientes y partículas alimenticias del continente. El avance de los sistemas deltaicos garantizó el rápido enterramiento y la preservación excepcional de los pectínidos.

Palabras clave: Tafonomía, concentraciones biológicas, Amusium balloti, Amusium pleuronectes, delta Abrioja.

\section{INTRODUCTION}

Amusium (Bivalvia; Pectinidae) is a tropical, Indo-Pacific scallop with about 20 extant species. Some of these species, such as the Asian moon scallop A. pleuronectes and the saucer scallop $A$. balloti, are extensively gathered for human consumption. The life histories and biology of these two species are the best known among representatives of the genus due to their commercial harvesting (Morton, 1980; Dredge, 1985a, 1985b; Belda \& Del Norte, 1988; Joll, 1989; Cropp, 1993; Joll \& Caputi, 1995a, 1995b; Kangas et al., 2006; Mueller et al., 2012; Tremblay et al., 2015).

As in other scallops, larvae of $A$. pleuronectes and $A$. balloti secrete a byssus, which is lost during ontogeny (Hayami, 1991; Rose et al., 1998; Wang et al., 2001; Kangas et al., 2006), thus remaining as free-living organisms with highly active swimming ability (Yonge, 1936; Gould, 1971; Hayami, 1991; Morton, 1980; Joll, 1989; Tremblay et al., 2015). In this respect, A. balloti is the best swimmer among scallops, reaching longest distances (up to $30 \mathrm{~m}$ in two swims), and fastest velocities (up to $160 \mathrm{~cm} \mathrm{~s}^{-1}$ ) (Joll, 1989). This swimming behaviour has been considered an adaptation primarily to escape from predators (Himmelman et al., 2009).

The spatial distribution of $A$. pleuronectes and A. balloti is controlled by different environmental factors, such as depth, temperature, substrate, currents, food, turbidity, oxygen content, and salinity (e.g. Brand, 2006; Mueller et al., 2012). Both species live on sandy bottoms swept by water currents, although the former species can tolerate a certain content of silt and mud in calmer waters (Young $\&$ Martin, 1989; Brand, 2006). They occupy a wide range of water depths, from a few meters to more than $100 \mathrm{~m}$ down (Brand, 2006). Within this broad bathymetric range, A. balloti is found mostly at $25-55 \mathrm{~m}$ deep in western Australia, while A. pleuronectes is preferentially distributed in slightly shallower waters, at 12-24 m deep in northern Australia or at $18-40 \mathrm{~m}$ in the Philippines (Kangas et al., 2006; Brand, 2006). In these depth ranges, both species form dense concentrations of individuals giving way to extensive, kilometre-scale beds (Kangas et al., 2006; Brand, 2006).
In the past geological record, Amusium species showed extratropical and wider geographic distributions. Among them, Amusium cristatum was a common inhabitant in the Mediterranean realm during the Neogene, at least up to the Pliocene (Raffi et al., 1985; Aguirre et al., 1996; Mandic, 2004; Jiménez et al., 2009; Dominici et al., 2009; Danise et al., 2010; Belaústegui et al., 2012). There are also Neogene records of this species in the Atlantic (Andrés \& de Porta, 1987; Demarq, 1990; Aguirre, 1995).

In the lower Pliocene deposits of the Almería-Níjar Basin (SE Spain) (Fig. 1), A. cristatum was a very common pectinid. It occurs as isolated individuals dispersed in finegrained sediments as well as in shell beds (Aguirre et al., 1996; Aguirre, 1998; Jiménez et al., 2009). In some of these shell beds, A. cristatum is a subsidiary component of multispecific assemblages accompanied, in order of abundance, by other bivalves (venerids, pectinids, and Neopycnodonte), and echinoids (regular cidaroids and infaunal spatangoids). The gastropod Scalaria, solitary corals (i.e. Flabellum and Caryophyllia), delicate and robust erect bryozoan colonies, and vertebrate remains (marine mammal bones, shark teeth, and complete and very well-preserved skate tail spines) can also be conspicuous components in some beds. The relative abundance of the accompanying organisms ranges from $30 \%$ to more than $50 \%$ of the total assemblage. Nonetheless, Amusium cristatum also occurs, forming monospecific-paucispecific concentrations (Aguirre, 1995, 1998, 2009; Aguirre et al., 1996; Jiménez et al., 2009).

Taphonomic analyses and sedimentological observations indicate that multispecific shell beds in the Almería-Níjar Basin were formed due to high-energy events, most likely storm events: 1) erosive bases, 2) fining-upward trends, 3) high taphonomic destruction of skeletal remains (high disarticulation, fragmentation, and abrasion), 4) imbrication of shells, and 5) concave-up stacked shells (Aguirre, 1995; Aguirre et al., 1996; Aguirre \& YesaresGarcía, 2003; Yesares-García \& Aguirre, 2004). However, the interpretation of the monospecific-paucispecific $A$. cristatum beds remains unclear. Aguirre (2009) suggested that they were the result of biological concentrations, but no detailed account of these beds were shown. In the present paper, a detailed sedimentological and taphonomical study 


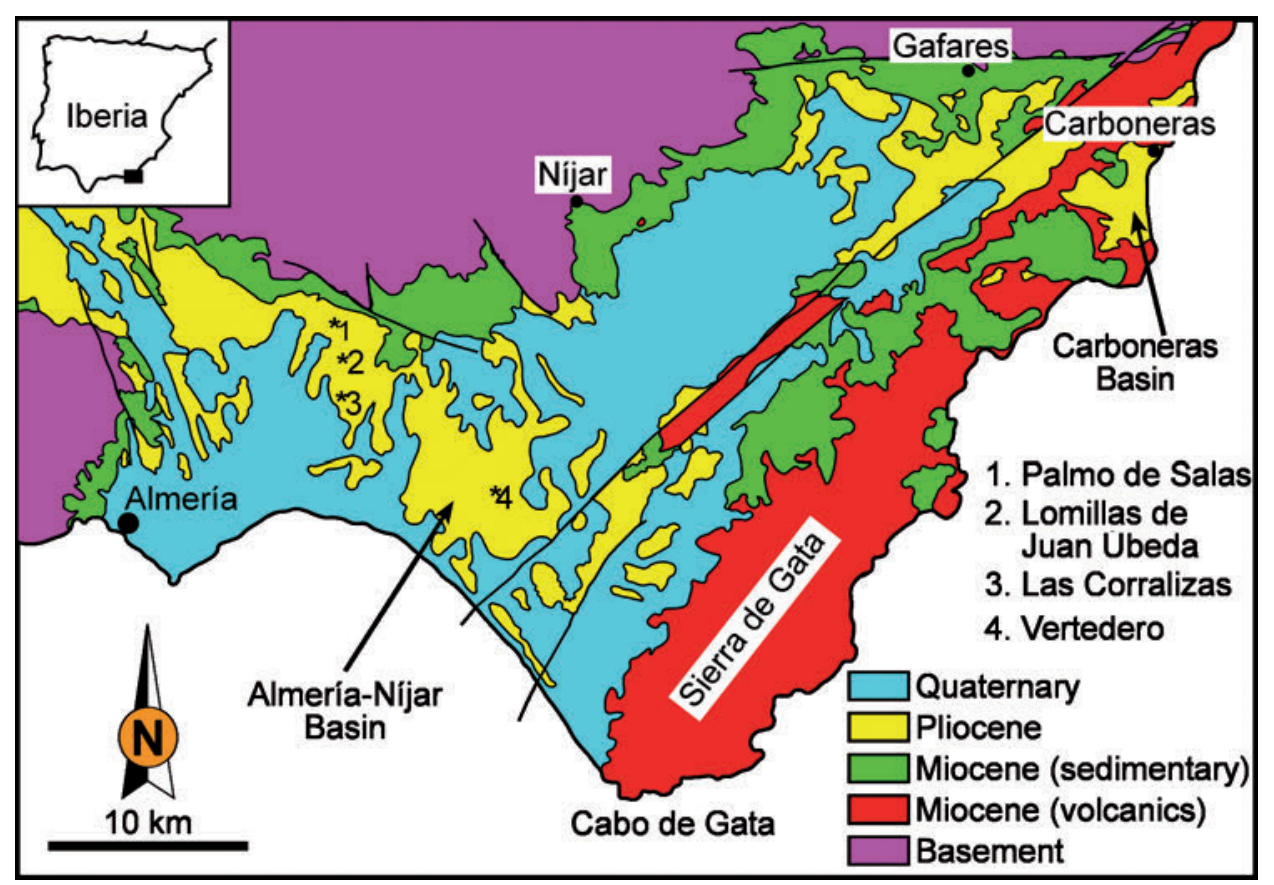

Figure 1. Geological map of the Almería-Níjar Basin and geographical location of the study sections. of these Amusium cristatum-dominated shell concentrations from the lower Pliocene deposits of the Almería-Níjar Basin (SE Spain) is presented in order to: a) characterize the shell beds based on taphonomic signatures, b) infer the processes involved in their formation, and c) deduce the palaeoenvironmental contexts in which these shell beds formed.

\section{MATERIAL AND METHODS}

As mentioned above, Amusium cristatum is present in numerous shell beds found throughout the Almería-Níjar Basin. Nonetheless, for the purposes of this work, the taphonomic study has been made in 15 monospecificpaucispecific shell beds dominated by $A$. cristatum (Fig. 2). Previous works in the area (Aguirre, 1995; Aguirre et al., 1996; Aguirre \& Yesares-García, 2003; Yesares-García \& Aguirre, 2004; Jiménez et al., 2009) have facilitated the selection of those shell beds that fit this requirement. The shell beds studied are distributed in four sections located following a proximal to distal position in the basin: Palmo de Salas, Lomillas de Juan Úbeda, Las Corralizas and Vertedero (Figs 1, 3). All these shell beds are intercalated in silts and fine-grained sands of prodelta facies of the Abrioja delta (see description below).

Sampling and quantitative analysis followed the methodological procedure extensively described by Aguirre \& Yesares-García (2003) and Yesares-García \& Aguirre (2004). The taphonomic attributes measured were: size sorting, articulation, fragmentation, angle with respect

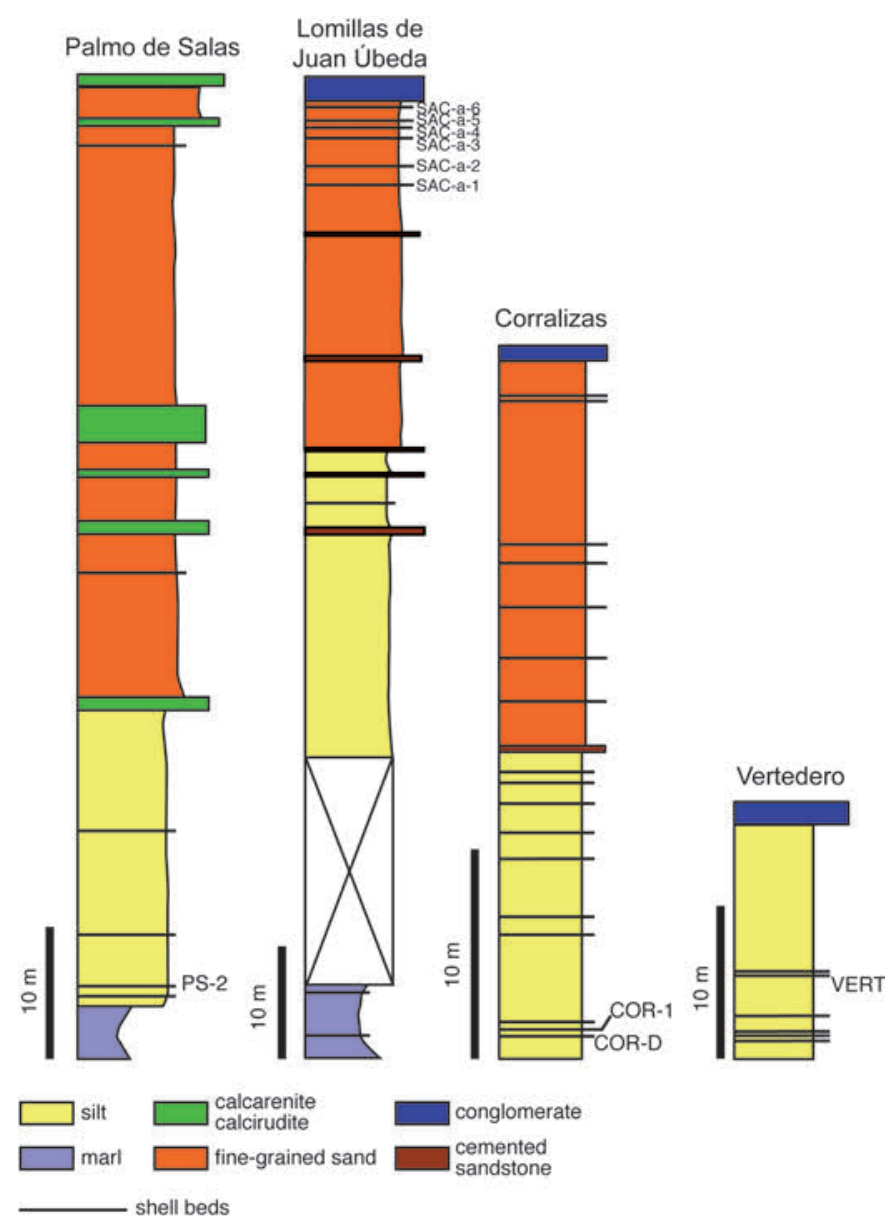

Figure 2. Stratigraphic logs indicating the position of the 15 shell beds studied. Abbreviations of the samples as in Table 1. Samples from SAC-II-1 to SAC-II-6 in Table 1 were collected about $500 \mathrm{~m}$ south of the laterally equivalent shell beds SAC-a-1 to SAC-a-6. 
to stratification (horizontal, oblique, perpendicular), life orientation, concavity orientation (up and down), skeletal preservation, edge rounding, and biotic interactions (borings and encrustations). Measurements of these taphonomic attributes were carried out in 10 quadrats $(20 \times 20 \mathrm{~cm})$, randomly distributed in each of the selected shell beds. Quadrats were oriented perpendicular to stratification. All fossils larger than $5 \mathrm{~mm}$ in cross-section found within the quadrats were quantified.

\section{GEOLOGICAL CONTEXT AND PALAEOGEOGRAPHY}

The Almería-Níjar Basin is an intermontane periMediterranean basin with a sedimentary infilling ranging from middle Miocene to Quaternary (Serrano, 1990; Montenat et al., 1990; Aguirre, 1998; Aguirre \& SánchezAlmazo, 2004). The basin was isolated after tectonic uplifting of the Betic basements (Sierra de Gádor, Sierra Alhamilla and Sierra Cabrera) and the volcanic province of Cabo de Gata during the late Miocene and MiocenePliocene transition (Braga et al., 2003a; Martín et al., 2003). This uplifting led to the compartmentalization of several basins and subbasins in the south-eastern part of the Iberian Peninsula (Montenat et al., 1990; Boorsma, 1992; Martín \& Braga, 1996; Aguirre, 1998; Braga et al., 2003a; Martín et al., 2003).

During the early Pliocene, the Almería-Níjar Basin was a large, open embayment in the north-west of the Alborán Basin, in the western Mediterranean. The basin was bordered by the Sierra de Gádor to the west, Sierra Alhamilla and Sierra Cabrera to the north, and the volcanic complex of the Sierra de Gata to the east (Fig. 3). The basin was connected to the Mediterranean by the south and by a narrow strait located in the north-eastern edge of the basin (Dabrio et al., 1986-87). At the end of the early Pliocene, the Almería-Níjar and the Carboneras basins, separated during most of the early Pliocene by a volcanic threshold at their closest point, coalesced and were connected due to the opening of some straits (Braga et al., 2003a, 2003b; Martín et al., 2003, 2004; Aguirre et al., 2008) (Fig. 3).

During the late Pliocene, the combined effect of the tectonic uplifting of the basement and a sea-level drop led to a major palaeogeographic change (Aguirre, 1998). Most of the basin was exposed and marine deposition took place in a restricted area located to the central part of the Almería-Níjar Basin (Aguirre \& Jiménez, 1997, 1998; Aguirre, 1998; Pérez-Asensio \& Aguirre, 2010). Extensive coral banks, made up by the scleractinian coral Cladocora caespitosa, characterized these deposits (Aguirre \& Jiménez, 1998).

The monospecific-paucispecific $A$. cristatum shell beds studied are in the lower Pliocene deposits of the AlmeríaNíjar Basin. A detailed description and interpretation of these sediments are provided elsewhere (Aguirre, 1998). Here, the general lithological facies description and the depositional contexts in which the shell beds are found is given below.

\section{THE LOWER PLIOCENE DEPOSITS OF THE ALMERÍA-NÍJAR BASIN}

The lower Pliocene deposits of the Almería-Níjar Basin onlap the Betic basement and an irregular palaeotopographic surface excavated on upper Miocene sediments (Montenat et al., 1990; Aguirre, 1998; Braga et al., 2003a, 2003b,

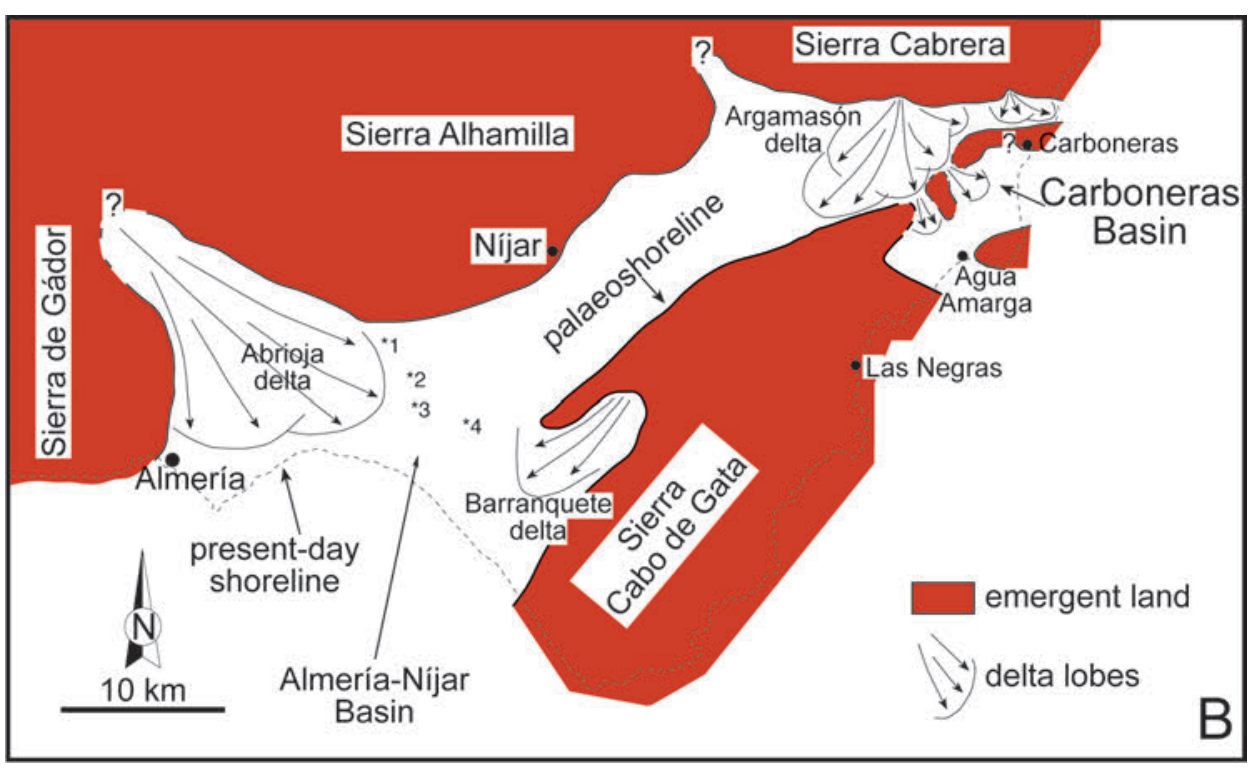

Figure 3. P a l a e g e o gra p h i c reconstruction of the Almería-Níjar Basin during the upper part of the early Pliocene, when this basin was connected with the Carboneras Basin. Numbers (as in Fig. 1) indicate the approximate position of the study sections. Modified from Braga et al. (2003b). 
Martín et al., 2003, 2004). These show a variety of lithologies and facies, represented mainly by terrigenous sediments and by carbonate-siliciclastic mixed deposits. Locally, in the Carboneras Basin, carbonate deposition prevailed during most of the early Pliocene (Aguirre, 1998; Braga et al., 2003b; Martín et al., 2003, 2004; Aguirre et al., 2008, 2012).

Siliciclastics derived from three major delta systems, the Abrioja delta in the north-western corner of the basin (Postma, 1979, 1983), the El Barranquete Gilbert-type delta associated with La Serrata area in the eastern of the basin (Boorsma, 1992), and the El Argamasón delta in the north-eastern edge (Aguirre, 1998) (Fig. 3). Other sources of siliciclastics were localized fan deltas fed by the Betic basements surrounding the basin (Aguirre, 1998).

Terrigenous particles are mostly metamorphic rocks (quartz, schist, and micaschist) from the Betic basement. In the eastern margin of the basin, the surrounding volcanic substrate of the Sierra de Gata was another source of siliciclastics, though limited to the base of the lower Pliocene sequence. Then, volcanic clasts disappeared and metamorphic clasts fed the basin. This change of the major clast components of the conglomerates points to an important tectonic uplifting of the Betic metamorphic basement to the north, Sierra Cabrera.

In a more distal position of the fan deltas and delta front, grain size decreases and the sediments change to coarse-grained and medium-grained sand. In the prodelta, fine-grained sand to silt were deposited (Postma, 1979, 1983). Finally, to the centre of the basin, blue-grey marl formed. The marls crop out only locally, the silt and the very fine-grained sand being the most extensive sediments outcropping in the distal positions of the basin. Amusium cristatum-dominated shell beds occur in these distal prodelta facies (Aguirre et al., 1996; Aguirre, 1998, 2009; Jiménez et al., 2009) (Fig. 2).

Carbonates crop out in the northern (Palmo de Salas, Gafares-El Argamasón areas) and western margins ( $\mathrm{N}$ of the city of Almería) of the Almería-Níjar Basin (Fig. 1). They are represented by bioclastic calcarenites and calcirudites deposited in areas of the platform starved by terrigenous inputs (Aguirre, 1998). Laterally, the carbonates change into siliciclastics of delta-front facies. Major components of the carbonates are bivalves, bryozoans, solitary corals, echinoids, brachiopods, barnacles, coralline red algae, and benthic foraminifers, all corresponding to heterozoan carbonate lithofacies (James, 1997). In the adjacent Carboneras Basin, heterozoan carbonate deposition prevailed during most of the early Pliocene (Aguirre, 1998; Braga et al., 2003b; Martín et al., 2004; Aguirre et al., 2012). Then, siliciclastic delta deposits prograded into the Carboneras Basin, thus suffocating the carbonate production that was limited to bivalves and barnacle concentrations (Aguirre et al., 2008, 2012).

\section{DESCRIPTION OF THE AMUSIUM CRISTATUM SHELL-BEDS}

The Amusium-dominated beds are among the most prominent and conspicuous features of fossil concentrations in the mid-to-distal prodelta silty facies of the AlmeríaNíjar Basin (Figs 4a-4c). Very rarely, they also interbed in sand and channelized conglomerates of the delta-front facies. They form single sheet-like concentrations that can be laterally followed in continuity for several tens to hundreds of meters (Fig. 4a). The Amusium beds vary in thickness from $5 \mathrm{~cm}$ to $15 \mathrm{~cm}$, and their base and the top are sharp and planar.

Shell abundance varies from $30 \%$ to $50 \%$ of the rock volume and the shells are loosely to densely packed. In terms of taxonomic composition, the shell beds are monospecific-paucispecific since they are almost exclusively dominated by Amusium cristatum that can represent more than $90 \%$ of the faunal composition.

Regarding the taphonomic attributes, fragmentation is relatively high on average $(77.9 \%)$, but most of the fragments show sharp edges (85.1\%; Table 1$)$ and preserve the original ornamentation in the inner part of the shells as well as the lustre of the outer surface and even the colour pattern (Figs 5a-5c). Disarticulated shells arrange mostly horizontally, showing a similar proportion of concaveup and -down orientation (Table 1; Fig. 5d). Articulation is relatively low except in the shell beds of Vertedero section, where $25.5 \%$ of Amusium are articulated (Table 1; Fig. 4b). Although disarticulated, a large portion of the shells is complete, averaging $22 \%$ (Table 1). In some beds, Amusium shows a distinct sequence of disarticulation from none to totally separated valves (Fig. 5d): 1) no disarticulation of valves, 2) valves slightly separated, i.e. the orientation of valves can be slightly ajar, 3) valves separated from one another, but still lying parallel to one another and somewhat overlap, 4) valves totally disarticulated, i.e. matching valves cannot be recognized in the sediment. There is a great dispersion of the size classes. Most of the fossils preserved the original shell mineralogy. The originally aragonitic organisms remain preserved as casts or moulds. When moulds are present, they are mostly articulated (Figs 4c, 5d) and show very delicate external shell ornamentation (such as growth lines, ridges, ribs, spines, etc.) or internal anatomical traits (such as muscle imprints, pallial line in the case of the bivalves, or septa in the case of the solitary corals). Epifaunal organisms, such as barnacles, are occasionally found on Chlamys shells. However, the most abundant taxon, Amusium, shows neither encrusting organisms nor borings. 

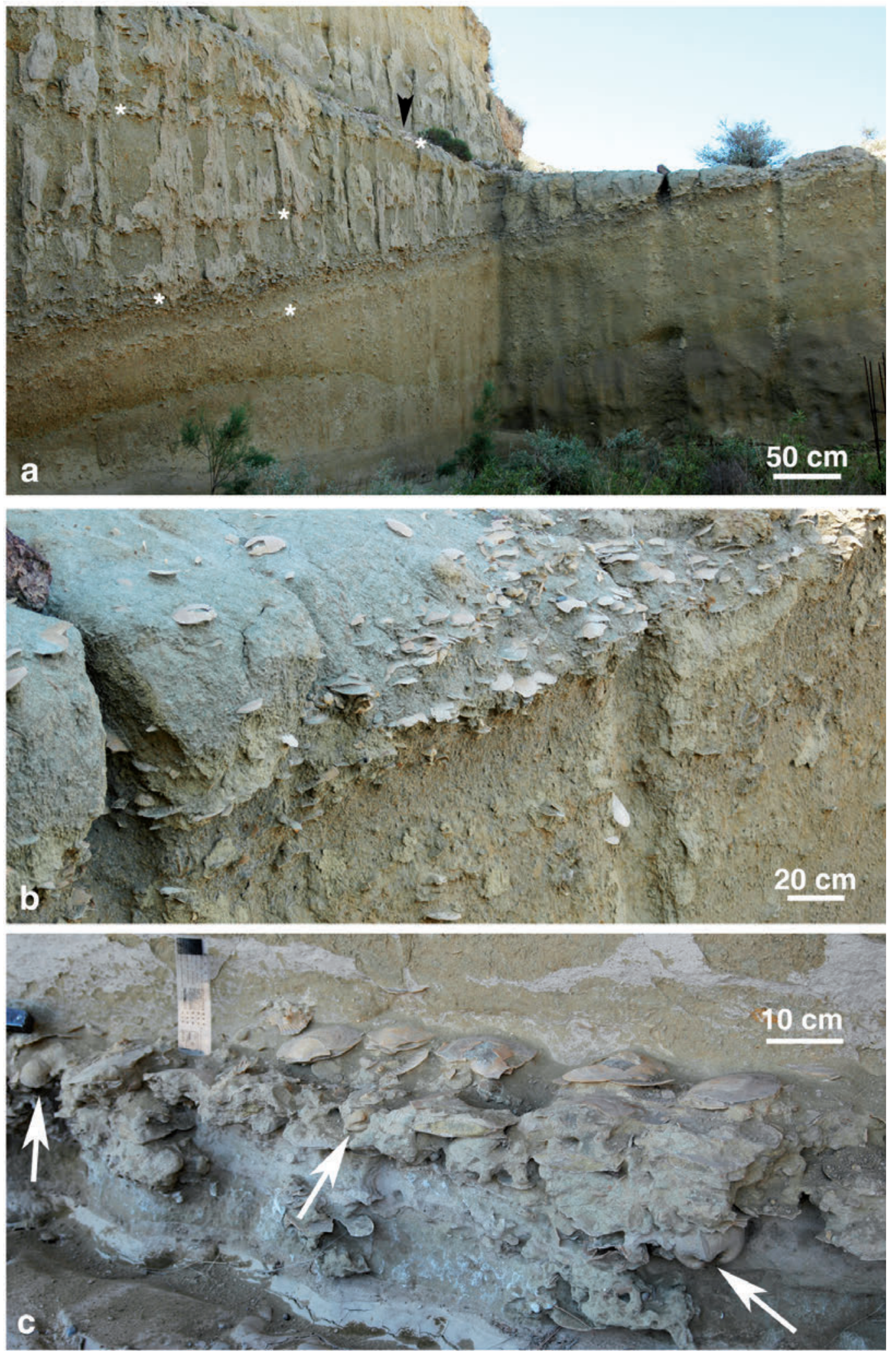

Figure 4. Examples of the Amusium cristatum beds from Vertedero (a, b) and Las Corralizas (c) sections. a) Several beds (asterisks) of $A$. cristatum from Vertedero section. Note the high concentration of shells and the lateral continuity of the beds. b) Detail of the uppermost shell bed of the previous picture (arrowhead in a). The high percentage of articulation and complete shells that can be seen are remarkable. The greenish colour of the sediment covering the $A$. cristatum bed is due to high concentration of glaucony. c) A. cristatum bed in the lowermost part of the Las Corralizas section (COR-D in Fig. 2). Together with the pectinid shells, several internal casts of different articulated bivalves are observed (arrows). 
Table 1. Average values of taphonomic attributes measured in the study sections. Values represent the average percentages calculated from the 10 quadrats distributed in each sampling site. The percentages were calculated with respect to the total number of fossils in each sampling site (column $\mathrm{n}$ ). frag. = fragmented; comp. = complete; art. = articulated; up = concave up; down $=$ concave down; round. $=$ rounded edges; indet. = indeterminate; encr. $=$ encrusted shells. SAC $=$ Lomillas de Juan Úbeda section; PS = Palmo de Salas section; COR = Corralizas section; VERT = Vertedero section.

\begin{tabular}{lrrrrrrrrrrrrrrrrrrrrr}
\hline & $\mathbf{n}$ & frag. & comp. & life & art. & up & down & vertical & platy & indet. & $\mathbf{0 - 3 0}$ & $\mathbf{3 0 - 6 0 ^ { \circ }}$ & $\mathbf{6 0 - 9 0}$ & original moulds sharp round. indet. boring encr. \\
\hline SAC-a-1 & 529 & 82,4 & 17,6 & 0 & 1,1 & 29,7 & 21,2 & 6,2 & 30,7 & 10,2 & 45,1 & 23,6 & 31,3 & 100 & 0 & 93,6 & 0 & 6,4 & 0 & 0 \\
SAC-a-2 & 288 & 67,7 & 32,3 & 0 & 1 & 27,1 & 26 & 7,3 & 32,3 & 7,3 & 59,4 & 20,8 & 19,8 & 100 & 0 & 96,9 & 3,1 & 0 & 0 & 0 \\
SAC-a-3 & 495 & 82,4 & 17,6 & 0,6 & 0,7 & 11,8 & 13,2 & 5,9 & 17,6 & 51,5 & 62,5 & 22,1 & 15,4 & 100 & 0 & 98,2 & 0,9 & 0,9 & 0,6 & 0 \\
SAC-a-4 & 345 & 93,6 & 6,4 & 0 & 0 & 29 & 24,1 & 0,9 & 41,4 & 4,6 & 73,9 & 11,7 & 10,4 & 100 & 0 & 93,6 & 0 & 6,4 & 0 & 0 \\
SAC-a-5 & 516 & 90,1 & 8,9 & 0 & 0,6 & 24,4 & 20,9 & 7,6 & 44,8 & 2,3 & 33,1 & 40,1 & 26,8 & 100 & 0 & 89,5 & 1,1 & 9,3 & 0 & 0 \\
SAC-a-6 & 300 & 80 & 20 & 0 & 2 & 30,3 & 34,7 & 0 & 33 & 2 & 45,5 & 42,6 & 11,9 & 100 & 0 & 76,7 & 0 & 23,3 & 0 & 0 \\
SAC-II-1 & 368 & 80,7 & 19,3 & 0 & 2,2 & 29,3 & 19,3 & 8,7 & 40,8 & 1,9 & 43,7 & 16,7 & 39,4 & 100 & 0 & 80,7 & 0 & 19,3 & 0 & 0 \\
SAC-II-2 & 225 & 78,4 & 21,6 & 0 & 1,4 & 23 & 23 & 9,6 & 40,5 & 1,3 & 45,9 & 23 & 31,1 & 100 & 0 & 78,4 & 0 & 21,6 & 0 & 0 \\
SAC-II-4 & 582 & 76,4 & 23,6 & 0 & 0 & 35,1 & 28,8 & 3,7 & 32,5 & 0 & 53,4 & 29,9 & 26,7 & 100 & 0 & 76,4 & 0 & 23,6 & 0,5 & 0 \\
SAC-II-5 & 381 & 81 & 19 & 0 & 1,6 & 32,5 & 26,2 & 0 & 38,1 & 3,2 & 46,1 & 39,7 & 14,2 & 100 & 0 & 80,6 & 0 & 19,4 & 0 & 0 \\
SAC-II-6 & 465 & 83,9 & 16,1 & 0 & 1,2 & 25,8 & 19,4 & 8,6 & 45,1 & 1,1 & 36,4 & 38,2 & 25,4 & 100 & 0 & 83,9 & 0 & 16,1 & 0 & 0 \\
COR-1 & 1148 & 72,2 & 27,8 & 1,8 & 8,5 & 29,9 & 17,2 & 3,9 & 20,2 & 28,7 & 80 & 14,3 & 5,7 & 56,1 & 43,9 & 41,2 & 0,4 & 58,4 & 0,8 & 1 \\
COR-D & 438 & 78,5 & 21,5 & 0 & 8,9 & 50,2 & 49,1 & 0 & 30,1 & 0 & 65,3 & 26,7 & 8 & 96,6 & 3,4 & 89,5 & 4,4 & 6,1 & 0 & 0 \\
PS-2 & 218 & 66,8 & 33,2 & 2,8 & 5,1 & 40,6 & 59,4 & 0 & 15,7 & 0 & 27,3 & 25,7 & 47 & 97,7 & 2,3 & 97,2 & 1,9 & 0,9 & 0 & 3,2 \\
VERT & 180 & 55 & 45 & 0 & 25,5 & 59,5 & 40,5 & 0 & 0 & 0 & 79 & 21 & 0 & 100 & 0 & 100 & 0 & 0 & 0 & 0 \\
\hline
\end{tabular}
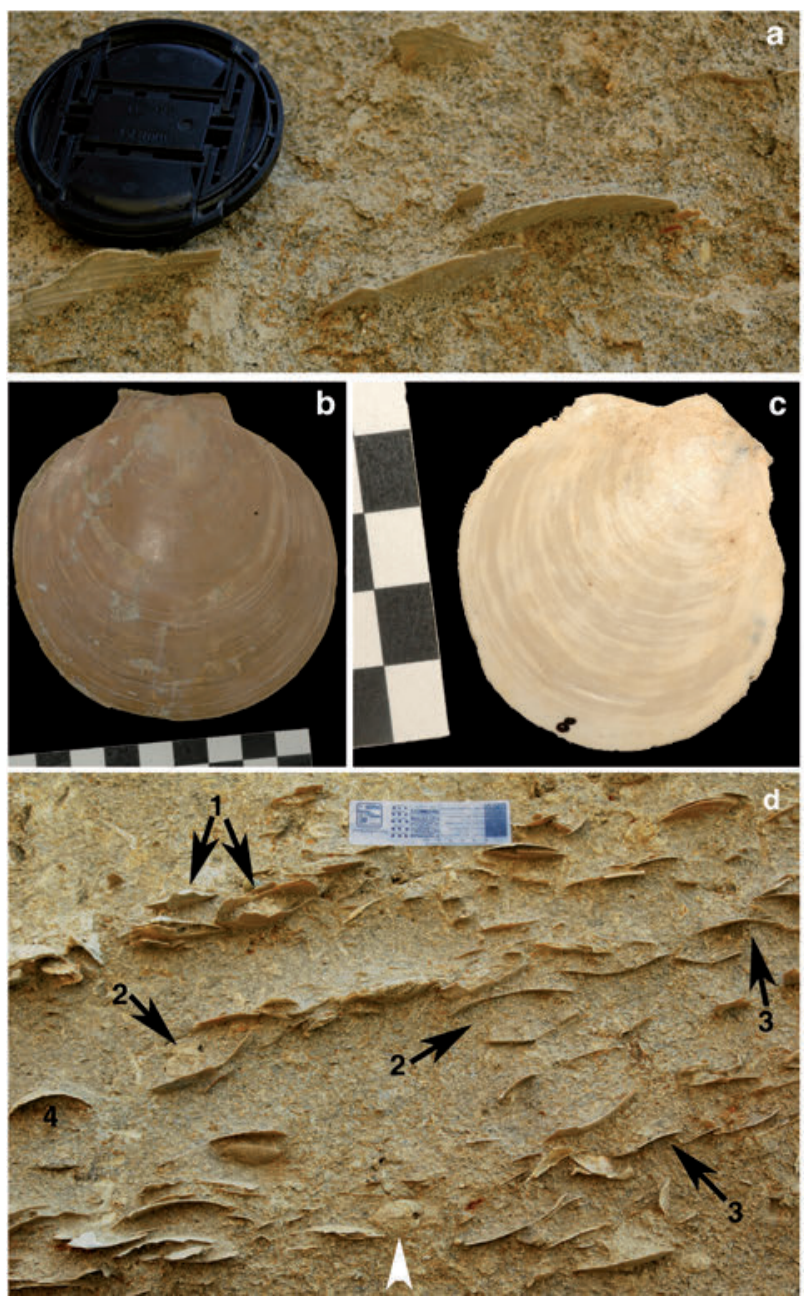

Figure 5. a) Disarticulated, but complete, Amusium shells from the Vertedero section. The radial ribs are visible in the inner surface of the shells. Lens cap $=58 \mathrm{~mm}$. b-c) Isolated shells of Amusium cristatum preserving traces of the original colour pattern and the lustre (c). d) Amusium concentration from Vertedero section (VERT in Fig. 2). Numerous shells are disarticulated but show sharp edges. Numbers 1 to 4 indicate different stages of disarticulation, from paired bivalves (1) to completely disarticulated shells (4) (see text for an explanation). The arrowhead indicates the internal cast of an articulated bivalve.

\section{DISCUSSION}

\subsection{Type of shell beds and palaeoenvironmental interpretation}

Kidwell et al. (1986) categorized shell concentrations as intrinsic or extrinsic accumulations. The former concentrations are the result of biological processes, i.e. due to gregarious behaviour of organisms, while the latter are the result of either sedimentary processes or of the activity of living organisms using/interacting with other skeletonized hard parts of death organisms (Kidwell et al., 1986). The taphonomic implications and the palaeoecological significance of the two types of 
concentrations are different. In particular, the biological accumulations can be non-time-averaged autochthonous (or parautochthonous) shell concentrations that were suddenly buried (Kidwell et al., 1986). Therefore, they constitute unique windows to assess ecological processes, such as population dynamics or community structures, which are very often distorted due to time averaging and taphonomic feedback (Kidwell et al., 1986; Kidwell \& Bosence, 1991; Kidwell, 1991a, 1991b). In marine settings, these accumulations typically imply intervals of reduced or no sedimentation, favouring the colonization of the seabed followed by catastrophic entombment (i.e. Aguirre \& Jiménez, 1997, 1998; Aguirre et al., 2008; Bassi et al., 2015).

Sedimentologic accumulations differ from the biological ones, since they are related to physical processes, such as hydraulic processes, producing reworked and allochthonous shell beds. In these cases, shells behave as sedimentary particles that remain in the taphonomic active zone (TAZ) for a long period of time, and are often subjected to reworking and transport. Typical examples are tempestites due to storms, or shell beds due to higher hydraulic energy events such as hurricanes or tsunamis (Aigner, 1985; Seilacher \& Aigner, 1991; Nummedal, 1991; Héquette \& Hill, 1993; Boyajian \& Thayer, 1995; Dattilo et al., 2008), as well as hiatal concentrations due to bypass (Beckvar \& Kidwell, 1988; Kidwell, 1989, 1991b, 1993; Rivas et al., 1997). These types of concentrations have a valuable sedimentary and sequence stratigraphic significance, since they form in particular settings and during particular sea-level conditions (Kidwell, 1986, 1988, 1989, 1991a, 1991b, 1993; Fürsich, 1995; Aguirre \& Yesares-García, 2003; Aguirre \& Méndez-Chazarra, 2010; Patzkowsky \& Holland, 2012).

In the Almería-Níjar Basin, A. cristatum can be a major constituent in shell beds intercalated in shallower settings, such as distal delta front or proximal prodelta facies (Aguirre et al., 1996). However, the monospecificpaucispecific $A$. cristatum shell beds are mostly interbeded in silt and very fine-grained sands in the central part of the basin. Benthic foraminiferal assemblages in these sediments are highly diversified and characterized by species preferentially distributed in the middle shelf (Aguirre et al., 2006). Occasionally, in situ preserved clumps of Neopycnodonte navicularis are present in these facies (Aguirre, 1998). This bivalve typically inhabits deep-water settings (Wissak et al., 2009), thus reinforcing the palaeoenvironmental interpretation.

Taphonomic analysis shows that Amusium cristatum did not undergo significant alteration or destruction. The ligament in A. cristatum, as well as in general in all pectinids, is small and prone to rapid decay. Therefore, a high percentage of articulation suggests low-energy conditions and limited exposure on the TAZ due to rapid entombment. Absence of bioerosion/encrustations, high proportion of complete shells and low abrasion, as well as the preservation of colour patterns in some Amusium shells, are all taphonomic features consistent with rapid burial. Advance of the prodelta facies to the centre of the basin guaranteed rapid burial of these shell concentrations. The sediment supply, in turn, also negatively affected these filter-feeding bivalves, causing their massive death. In short, taphonomic analysis shows that $A$. cristatum concentrations in the lower Pliocene deposits of the Almería-Níjar Basin can be interpreted as biological concentrations sensu Kidwell et al. (1986).

\subsection{Origin of the biological concentrations of A. cristatum}

Numerous scallop species tend towards gregarious behaviour, forming large and dense concentrations of individuals (Dredge, 1988; Stokesbury \& Himmelman, 1993; Hatcher et al., 1996; Brand, 2006; Orensanz et al., 2006; Kangas et al., 2006). Formation of these dense settlements depends upon complex interactions of physical and biological factors affecting the standing stock of adult populations, their spawning, their recruitment, and their larval dispersal (see a summary in Orensanz et al., 2006). Nonetheless, the proximal ecological causes behind this gregarious behaviour in particular cases are not well understood. In this respect, Young et al. (1990, p. 80), studying the recruitment of Pecten fumatus populations, stated "that while the size of the population of larvae competent to settle is related to the parental stock, the number actually settling on the bottom is dependent upon some, as yet unknown, characteristics of the physical and biological environment at the settlement site".

It has been speculated, based on the capacity to actively swim, that aggregations of recent $A$. balloti could be related to long-distance displacements or migrations (Yonge, 1936; Baird, 1954; Morton, 1980; Chapman, 1981). These massive migrations would produce large concentrations of individuals. Nonetheless, Joll (1989) demonstrated that A. balloti, which is the best swimmer among scallops, was unable to maintain a sustained swim. In a study of 55 individuals of $A$. balloti, 46 of them (83\%) remained resting on the bottom after two swims, with only one individual being able to swim up to four times. In addition, the longest distance achieved by all scallops was $30.8 \mathrm{~m}$ (Joll, 1989). Therefore, these results do not support the idea of large-distance migrations (Joll, 1989; Brand, 2006).

In many cases, scallop aggregations follow irregular and unpredictable pulses of population blooms followed by dramatic reductions. Global-regional temperature variations and/or oceanographic patterns most likely account for these sporadic changes in abundance (Orensanz et al., 2006). Recent $A$. balloti produces dense populations distributed for kilometres in sheltered areas of the Shark Bay, western 
Australia (Dredge, 1990; Joll, 1990; Kangas et al., 2006; Mueller et al., 2012). Here, the species undergoes abrupt changes in population dynamics that have been linked to the Leeuwin Current, which is in turn influenced by the El Niño-Southern Oscillation (ENSO) events (Joll \& Caputi, 1995b). According to these authors, an intensification of the Leeuwin Current produces a corresponding dramatic reduction in A. balloti populations.

Other authors have proposed that the recent massive occurrences of Amusium may be related to the preferential orientation of individuals with water currents based on the large-scale morphology of the aggregations (Heald \& Caputi, 1981; Dredge, 1985b). It has been noted that long and thin concentrations of $A$. balloti are parallel to tidal currents, suggesting that larvae settled within strong current areas (Brand, 2006). This author also stated that these concentrations could be the result of active downstream swimming following the strong currents.

In our study case, it is difficult to apply any of these actualistic approaches to account for the massive occurrences of A. cristatum. It is possible, however, to discard the distribution of Amusium concentrations following a particular water current, since they formed in silty deposits without any evidence of high-energy currents. However, the spatial distribution of the beds, the palaeogeographic configuration of the Almería-Níjar Basin during the early Pliocene, and additional microfossil data help to envisage the origin of these shell beds.

Although the presence of Amusium cristatum is widespread in the lower Pliocene deposits of the AlmeríaNíjar Basin, the monospecific-paucispecific biological concentrations formed by this species are restricted to the central part of the basin. Palaeogeographically, the basin was a semi-enclosed bay mainly open to the south during the early Pliocene (Fig. 3). Coincidently, recent large and massive occurrences of Amusium species are in partially enclosed bays, such as the well-known examples of extensive A. balloti beds in the protected areas of the Shark Bay (W Australia) (Joll, 1989; Kangas et al., 2006; Mueller et al., 2012). Here, these beds develop in water between 10 and $75 \mathrm{~m}$ deep. The Pliocene A. cristatum biological beds were preserved in mid-shelf settings, as inferred from the benthic foraminiferal assemblages found in the prodelta facies (Aguirre et al., 2006). Pérez-Muñoz et al. (2001) inferred a maximum water depth of $\sim 100 \mathrm{~m}$ for the silts along the northern margin of the Almería-Níjar Basin. This depth is close to, or even slightly greater than, the water-depth range of the recent $A$. balloti in western Australia. It is reasonable to assume that $A$. cristatum also formed biological concentrations in shallower waters, as A. balloti does today. Nevertheless, storm events might distort these concentrations and lead $A$. cristatum shells to be part of tempestites as shell fragments.

In addition, the benthic foraminiferal assemblages indicate a mesotrophic environment shown by a mixture of species from eutrophic and oligotrophic conditions (Aguirre et al., 2006). The supply of nutrients and food particles by the deltas outflowing into the basin accounts for the establishment of mesotrophic conditions widespread in the centre of the basin (Aguirre et al., 2006). The continuous supply of food would have triggered demographic blooms of $A$. cristatum populations, forming extensive concentrations. Similarly, dense populations of $A$. balloti in the Shark Bay are favoured when water eddies linked to oceanographic conditions concentrate food particles in localized areas of the basin (Heald \& Caputi, 1981; Orensanz et al., 2006).

The continuous source of nutrients and food particles to the bottom of the basin eventually produce disoxyc conditions (Aguirre et al., 2006). These events of oxygen reduction on the sea floor could trigger massive death of local populations of $A$. cristatum. Therefore, the sporadic depletion of oxygen close to the water-sediment interface, together with the continuous sediment supply due to delta progradation, guaranteed catastrophic death of local populations and sudden burial, leading the exceptional preservation of shells in the $A$. cristatum monospecificpaucispecific biological concentrations.

\section{CONCLUSIONS}

1. The pectinid Amusium cristatum formed monospecificpaucispecific dense concentrations in very fine-grained sand and silt of the Almería-Níjar Basin (SE Spain) during the early Pliocene. These sediments correspond to distal prodelta sediments deposited in mid-shelf settings.

2. Upper and lower contacts of the beds are sharp. Quantitative taphonomic analysis indicates relatively high percentage of articulation, low fragmentation, and almost absence of abrasion. Many shells preserve the patterns of the original colouration. Disarticulated shells occur concave-up and down, sorting is very poor and they are unaffected by encrusting organisms or borings. These taphonomic signatures indicate nearly in situ preservation without reworking and exceptional preservation due to rapid burial. They represent biological concentrations sensu Kidwell et al. (1986).

3. Amusium cristatum beds formed in the centre of the Almería-Níjar Basin, a wide and relatively sheltered palaeobay. Benthic foraminiferal assemblages found in the prodelta sediments suggest mesotrophic conditions with a supply of nutrients and food particles from the continent due to the progradation of delta systems. The extra supply of nutrients produced blooms of scallop populations. Then, the advance of deltas to the centre of the basin led rapid entombment of local populations.

4. The present-day scallop species Amusium balloti and A. pleuronectes form similar dense concentrations. 
The former species develops large accumulations in the Shark Bay (NW Australia) from 10 to $75 \mathrm{~m}$ depth. The greatest water-depth distribution is similar to the palaeobathymetry inferred for the A. cristatum shell beds intercalated in the lower Pliocene prodelta deposits of the Almería-Nijar Basin. The recent shell beds of $A$. balloti can be considered a present-day counterpart of $A$. cristatum accumulations.

\section{ACKNOWLEDGEMENTS}

I greatly appreciate the thorough review of the paper by Drs R. Domènech and J.A. González-Delgado; their comments and suggestions have helped to improve the quality of the manuscript. I also greatly appreciate the fruitful discussions with J. Nebelsik in the field on the Amusium shell beds. This paper has been partially supported by the Research Project CGL2003-47236-P of the Ministerio de Economía y Competitividad of the Spanish Government, the Research Group RNM-190 of the Junta de Andalucía, and the Fondo Europeo del Desarrollo Regional (FEDER). David Nesbit corrected the English text.

\section{REFERENCES}

Aguirre, J. 1995. Implicaciones paleoambientales y paleogeográficas de dos discontinuidades estratigráficas en los depósitos pliocénicos de Cádiz (SW de España). Revista de la Sociedad Geológica de España, 8, 161-174.

Aguirre, J. 1998. El Plioceno del SE de la Península Ibérica (Provincia de Almería). Síntesis estratigráfica, sedimentaria, bioestratigráfica y paleogeográfica: Revista de la Sociedad Geológica de España, 11, 297-315.

Aguirre, J. 2009. Biological concentrations of Amusium cristatum. Journal of Taphonomy, 2-3, 263-264.

Aguirre, J. \& Jiménez, A.P. 1997. Census assemblages in hard-bottom coastal communities: a case study from the Plio-Pleistocene Mediterranean. Palaios, 12, 598-608; doi: $10.2307 / 3515415$.

Aguirre, J. \& Jiménez, A.P. 1998. Fossil analogues of the present-day ahermatypic Cladocora caespitosa coral banks: Sedimentary setting, dwelling community, and taphonomy (Late Pliocene, W Mediterranean). Coral Reefs, 17, 203-213; doi: 10.1007/s003380050119.

Aguirre, J. \& Méndez-Chazarra, N. 2010. Tafonomía de los carbonatos templados pliocenos de la Cuenca de Almayate (Málaga, S de España). Revista Española de Paleontología, 25, 149-163.

Aguirre, J. \& Sánchez-Almazo, I.M. 2004. The Messinian post-evaporitic deposits of the Gafares area (Almería, SE Spain). A new view of the "Lago-Mare" facies.
Sedimentary Geology, 168, 71-95; doi: 10.1016/j. sedgeo.2004.03.004.

Aguirre, J. \& Yesares-García, J. 2003. Análisis tafonómico y secuencial del Plioceno inferior en el sector NE de la cuenca de Almería-Níjar (SE de España). Revista Española de Paleontología, 18, 61-82.

Aguirre, J., Pérez-Muñoz, A.B. \& Sánchez-Almazo, I.M. 2006. Benthic foraminifer assemblages in the lower Pliocene deposits of the Almería-Níjar Basin (SE Spain). Revista Española de Micropaleontología, 38, 411-428.

Aguirre, J., Braga, J.C., Jiménez, A.P. \& Rivas, P. 1996. Substrate-related changes in pectinid fossil assemblages. Palaeogeography, Palaeoclimatology, Palaeoecology, 126, 291-308; doi: 10.1016/S0031-0182(96)00042-9.

Aguirre, J., Braga, J.C., Martín, J.M. \& Betzler, C. 2012. Palaeoenvironmental and stratigraphic significance of Pliocene rhodolith beds and coralline algal bioconstructions from the Carboneras Basin (SE Spain). Geodiversitas, 34, 115-136; doi: 10.5252/g2012n1a7.

Aguirre, J., Martín, J.M., Braga, J.C., Betzler, C., Berning, B.B. \& Buckeridge, J.S. 2008. Densely-packed concentrations of sessile barnacles (Cirripedia: Sessilia) from the early Pliocene of SE Spain. Facies, 54, 193-206; doi: 10.1007/ s10347-007-0132-2.

Aigner, T. 1985. Storm Depositional Systems. Dynamic, Stratigraphy in Modern and Ancient Shallow-Marine Sequences. Springer-Verlag, Berlin.

Andrés, I. \& de Porta, J. 1987. La distribución de los Pectinidae en el Neógeno de Huelva. Datos preliminaries. In: Paleontología del Neógeno de Huelva (W. Cuenca del Guadalquivir) (ed. Civis, J.). Dpto. de Paleontología, Universidad de Salamanca, Salamanca, 143-151.

Baird, F.T., Jr. 1954. Migration of the deep sea scallop Pecten magellanicus. Maine Department of Sea Shore Fisheries Circ., 14, 1-8.

Bassi, D., Posenato, R. \& Nebelsick, J.H. 2015. Paleoecological dynamics of shallow-water bivalve carpets from a lower Jurassic lagoonal setting, northeast Italy. Palaios, 30, 758-770; doi: 10.2110/palo.2015.020.

Beckvar, N. \& Kidwell, S.M. 1988. Hiatal shell concentrations, sequence analysis, and sealevel history of a Pleistocene coastal alluvial fan, Punta Chueca, Sonora. Lethaia, 21, 257-270; doi: 10.1111/j.1502-3931.1988.tb02078.x.

Belaústegui, Z., de Gibert, J.M., Domènech, R., Muñiz, F. \& Martinell, J. 2012. Clavate borings in a Miocene cetacean skeleton from Tarragona (NE Spain) and the fossil record of marine bone bioerosion. Palaeogeography, Palaeoclimatology, Palaeoecology, 323-325: 68-74; doi: 10.1016/j.palaeo.2012.01.031.

Belda, C.A. \& Del Norte, A.G.C. 1988. Notes on the induced spawning and larval rearing of the Asian moon scallop, Amusium pleuronectes (Linné), in the laboratory. Aquaculture, 72, 173-179; doi: 10.1016/00448486(88)90157-3.

Boorsma, L.J. 1992. Syn-tectonic sedimentation in a Neogene strike-slip basin containing a staked Gilbert-type delta (SE Spain). Sedimentary Geology, 81, 105-123; doi: 10.1016/0037-0738(92)90059-Z. 
Boyajian, G.E. \& Thayer, C.W. 1995. Clam calamity: a recent supratidal storm-deposit as an analogue for fossil shell beds. Palaios, 10, 484-489; doi: 10.2307/3515051.

Braga, J.C., Martín, J.M. \& Quesada, C. 2003a. Patterns and average rates of late Neogene-Recent uplift of the Betic Cordillera, SE Spain. Geomorphology, 50, 3-26; doi: 10.1016/S0169-555X(02)00205-2.

Braga, J.C., Betzler, C., Martín, J.M. \& Aguirre, J. 2003b. Spit-platform temperate carbonates: the origin of landward-downlapping beds along a basin margin (lower Pliocene, Carboneras basin, SE Spain). Sedimentology, 50, 553-563; doi: 10.1046/j.1365-3091.2003.00564.x.

Brand, A.R. 2006. Scallop ecology: Distribution and behaviour. In: Scallops: Biology, Ecology and Aquaculture (eds Shumway, S.E. \& Parsons, G.J.). Elsevier, Amsterdam, 651-744.

Chapman, C.J. 1981. The swimming behaviour of queens in relation to trawling. Scottish Fishering Bulletin, 46, 7-10.

Cropp, D.A. 1993. Development of large-scale hatchery production techniques for Amusium balloti (Bernardi 1861) in western Australia. Aquaculture, 115, 285-296; doi: 10.1016/0044-8486(93)90143-M.

Dabrio, C.J. 1987-86. Las sand waves calcareníticas del Río Alías (Mioplioceno de la Cuenca de Níjar, Almería). Acta Geológica Hispánica, 21-22, 159-166.

Danise, S., Dominici, S. \& Betocchi, U. 2010. Mollusk species at a Pliocene shelf whale fall (Orciano Pisano, Tuscany). Palaios, 25, 449-456; doi: 10.2110/palo.2009. p09-139r.

Dattilo, B.F., Brett, C.E., Tsujita, C.J. \& Fairhurst, R. 2008. Sediment supply versus storm winnowing in the development of muddy and shelly interbeds from the Upper Ordovician of the Cincinnati region, USA. Journal of Canadian Earth Sciences, 45, 243-265; doi: 10.1139/ E07-060.

Demarq, G. 1990. Pectinidés Néogènes: proposition d'échelle biostratigraphique pour la Méditerranée. Geobios, 23, 149159; doi: 10.1016/S0016-6995(06)80047-1.

Dominici, S., Cioppi, E., Danise, S., Betocchi, U., Gallai, G., Tangocci, F., Valleri, G. \& Monechi, S. 2009, Mediterranean fossil whale falls and the adaptation of mollusks to extreme habitats. Geology, 37, 815-818; doi: 10.1130/G30073A.1.

Dredge, M. 1985a. Estimates of natural mortality and yieldper-recruit for Amusium japonicum balloti Bernardi (Pectinidae) based on tag recoveries. Journal of Shellfish Research, 5, 103-109.

Dredge, M. 1985b. Growth and mortality in an isolated bed of saucer scallops, Amusium japonicum balloti (Bernard). Queensland Journal of Agricultural Animal Science, 42, 11-21.

Dredge, M. 1988. Recruitment overfishing in a tropical scallop fishery? Journal of Shellfish Research 7, 223-239.

Dredge, M. 1990. How far can a scallop population be pushed? In: Proceedings of the Australasian scallop workshop (eds Dredge, M.C.L., Zacharin, W.F. \& Joll, L.M.). Hobart, Australia, 68-79.
Fürsich, F.T. 1995. Shell concentrations. Eclogae geologicae Helvetiae, 88, 643-655.

Gould, S.J. 1971. Muscular mechanics and the ontogeny of swimming in scallops. Palaeontology, 14, 61-94.

Hatcher, B.G., Scheibling, R.E., Barbeau, M.A., Hennigar, A.W., Taylor, L.H. \& Windust, A.J. 1996. Dispersion and mortality of a population of sea scallop (Placopecten magellanicus) seeded in a tidal channel. Canadian Journal of Fishery Aquatic Sciences, 53, 38-54.

Hayami, I. 1991. Living and fossil scallop shells as airfoils: an experimental study. Paleobiology, 17, 1-18.

Heald, D.I. \& Caputi, N. 1981. Some aspects of growth, recruitment and reproduction in the southern saucer scallop, Amusium balloti (Bernardi, 1861) in Shark Bay, Western Australia. Fishery Research Western Australia. $25,1-33$.

Héquette, A. \& Hill, P.R. 1993. Storm-generated currents and offshore sediment transport on a sandy shoreface, Tibjak Beach, Canadian Beaufort Sea. Marine Geology, 113, 283-304; doi: 10.1016/0025-3227(93)90023-O.

Himmelman, J.H., Guderley, H.E. \& Duncan, P.F. 2009. Responses of the saucer scallop Amusium balloti to potential predators. Journal of Experimental Marine Biology and Ecology, 378, 58-61; doi: 10.1016/j. jembe.2009.07.029.

James, N.P. 1997. The cool-water carbonate depositional realm. In: Cool-Water Carbonates (eds James, N.P. \& Clarck, A.D.). SEMP Special Publication, 56, 1-20.

Jiménez, A.P., Aguirre, J. \& Rivas, P. 2009. Taxonomic study of scallops (Pectinidae: Mollusca, Bivalvia) from Pliocene deposits (Almería, SE Spain). Revista Española de Paleontología, 24, 1-30.

Joll, L.M. 1989. Swimming behaviour of the saucer scallop Amusium balloti (Mollusca: Pectinidae). Marine Biology, 102, 299-305; doi: 10.1007/BF00428481.

Joll, L.M. 1990. Recruitment variation in stocks of the saucer scallop Amusium balloti in the Abrolhos Island area. In: Proceedings of the Australasian scallop workshop (eds Dredge, M.C.L., Zacharin, W.F. \& Joll, L.M.). Hobart, Australia, 61-67.

Joll, L.M. \& Caputi, N. 1995a. Geographic variation in the reproductive cycle of the saucer scallop, Amusium balloti (Bernardi, 1861) (Mollusca: Pectinidae), along the Western Australian coast. Marine and Freshwater Research, 46, 779-792; doi: 10.1071/MF9950779.

Joll, L.M. \& Caputi, N. 1995b. Environmental influences on recruitment in the Shark Bay saucer scallop (Amusium balloti) fishery of Shark Bay, Western Australia. ICES Marine Science Symposia, 199, 47-53.

Kangas, M., Weir, V., Fletcher, W. \& Sporer, E. 2006. Shark Bay Scallop Fishery. ESD Report Series No. 2, Department of Fisheries, Western Australia, North Beach WA.

Kidwell, S.M. 1986. Models for fossil concentrations: Paleobiological implications. Paleobiology, 12, 6-24; doi: 10.1017/S0094837300002943.

Kidwell, S.M. 1988. Taphonomic comparison of passive and active continental margins: Neogene shell beds of the Atlantic coastal plain and northern Gulf of California. 
Palaeogeography, Palaeoclimatology, Palaeoecology, 63, 201-223; doi: 10.1016/0031-0182(88)90097-1.

Kidwell, S.M. 1989. Stratigraphic condensation of marine transgressive records: Origin of major shell deposits in the Miocene of Maryland. Journal of Geology, 97, 1-24.

Kidwell, S.M. 1991a. The stratigraphy of shell concentrations. In: Taphonomy. Releasing the Data Locked in the Fossil Record (eds Allison, P.A. \& Briggs, D.E.G.). Topics in Geobiology. Plenum, New York, 211-290.

Kidwell, S.M. 1991b. Condensed deposits in siliciclastic sequences: Expected and observed features. In: Cycles and Events in Stratigraphy (eds Einsele, G., Ricken, W. \& Seilacher, A.). Springer-Verlag, Berlin, 682-695.

Kidwell, S.M. 1993. Taphonomic expressions of sedimentary hiatuses: Field observations on bioclastic concentrations and sequence anatomy in low, moderate and high subsidence settings. Geologische Rundschau, 28, 189-202; doi: 10.1007/BF00191825.

Kidwell, S.M. \& Bosence, D.W.J. 1991. Taphonomy and time-averaging of marine shelly faunas. In: Taphonomy. Releasing the Data Locked in the Fossil Record (eds Allison, P.A. \& Briggs, D.E.G.). Topics in Geobiology. Plenum, New York, 115-209.

Kidwell, S.M., Fürsich, F.T. \& Aigner, T. 1986. Conceptual framework of the analysis and classification of fossil concentrations. Palaios, 1, 228-238; doi: 10.2307/3514687.

Mandic, O. 2004. Pectinid bivalves from the Ground Formation (lower Badenian, middle Miocene, Alpine-Carpathian foredeep) - Taxonomic revision and stratigraphic significance. Geologica Carpathica, 55, 129-146.

Martín, J.M. \& Braga, J.C. 1996. Tectonic signals in the Messinian stratigraphy of the Sorbas basin (Almería, SE Spain). In: Tertiary Basins of Spain: The Stratigraphic Record of Crustal Kinematics (eds Friend, P.F. \& Dabrio, C.J.). World and Regional Geology Series, Cambridge University Press, Cambridge, 6, 387-391.

Martín, J.M., Braga, J.C. \& Betzler, C. 2003. Late NeogeneRecent uplift of the Cabo de Gata volcanic province, Almería, SE Spain. Geomorphology, 50, 27-42; doi: 10.1016/S0169-555X(02)00206-4.

Martín, J.M., Braga, J.C., Aguirre, J. \& Betzler, C. 2004. Contrasting models of temperate carbonate sedimentation in a small Mediterranean embayment: the Pliocene Carboneras basin, SE Spain. Journal of the Geological Society, London, 161, 387-399; doi: 10.1144/0016764903-044.

Montenat, C., Ott d'Estevou, P. \& La Chapelle, G. 1990. La bassin de Níjar-Carboneras et le couloir du bas-Andarax. In: Les Bassins Néogènes du Domaine Bétique Oriental (Espagne): Tectonique et Sedimentation dans un Couloir de Decrochement. Premiere Partie: Etude Regionale (ed. Montenat, C.). Documents et Travaux, Institut Geologique Albert-de-Lapparent, 12-13, 129-164.

Morton, B. 1980. Swimming in Amusium pleuronectes (Bivalvia: Pectinidae). Journal of Zoology, 190, 375-404; doi: 10.1111/j.1469-7998.1980.tb01434.x.

Mueller, U., Kangas, M., Sporer, E. \& Caputi, N. 2012. Variability in the spatial and temporal distribution of the saucer scallop, Amusium balloti, in Shark Bay management implications. Marine and Freshwater Research, 63, 1152-1164; doi: 10.1071/MF12051.

Nummedal, D. 1991. Shallow marine storm sedimentation the oceanographic perspective. In: Cycles and Events in Stratigraphy (eds Einsele, G., Ricken, W. \& Seilacher, A.). Springer-Verlag, Berlin, pp. 227-248.

Orensanz, J.M., Parma, A.M., Turk, T. \& Valero, J. 2006. Dynamics, assessment and management of exploited natural populations. In: Scallops: Biology, Ecology and Aquaculture (eds Shumway, S.E. \& Parsons, G.J.). Elsevier, Amsterdam, 765-868.

Patzkowsky, M.E. \& Holland, S.M. 2012. Stratigraphic Paleobiology. Understanding the Distribution of Fossil Taxa in Time and Space. The University of Chicago Press. Chicago, USA.

Pérez-Asensio, J.N. \& Aguirre, J. 2010. Benthic foraminiferal assemblages in temperate coral-bearing deposits from the late Pliocene. Journal of Foraminiferal Research, 40, 6178; doi: 10.2113/gsjfr.40.1.61.

Pérez-Muñoz, A.B., Márquez-Crespo, R., Yesares-García, J., Sánchez-Almazo, I.M. \& Aguirre, J. 2001. Evolución paleoambiental durante el Plioceno inferior en la Cuenca de Almería-Níjar (SE de España) según las asociaciones de foraminíferos bentónicos. Revista Española de Paleontología, $\mathrm{N}^{\circ}$ extra, 21-34.

Postma, G. 1979. Preliminary note on a significant sequence in conglomeratic flows of a mass-transport dominated fan-delta (lower Pliocene, Almeria Basin, SE Spain). Proceedings Kon. Nederland Akademie van Wet., Serie $B, 82,465-471$.

Postma, G. 1983. Water-scape structures in the context of a depositional model of a mass flow dominated conglomeratic fan-delta (Abrioja Formation, Pliocene, Almeria Basin, SE Spain). Sedimentology, 30, 91-103; doi: 10.1111/j.1365-3091.1983.tb00652.x.

Raffi, S., Stanley, S.M. \& Marasti, R. 1985. Biogeographic patterns and Plio-Pleistocene extinction of Bivalvia in the Mediterranean and southern North Sea. Paleobiology, 11, 368-388.

Rivas, R., Aguirre, J. \& Braga, J.C. 1997. Entolium beds: hiatal shell concentrations in starved pelagic settings (middle Liassic, SE Spain). Eclogae geologicae Helvetiae, 90, 293-301.

Rose, R.A., Campbell, G.B. \& Sanders, S.G. 1998. Larval development of the saucer scallop Amusium balloti, Bernardi (Mollusca: Pectinidae). Australian Journal of Marine and Freshwater Research, 39, 133-160; doi: 10.1071/MF9880153.

Seilacher, A. \& Aigner, T. 1991. Storm deposition at the bed, facies and basin scale: The geologic perspective. In: Cycles and Events in Stratigraphy (eds Einsele, G., Ricken, W. \& Seilacher, A.). Springer-Verlag, Berlin, pp. 249-267.

Serrano, F. 1990. El Mioceno medio en el área de Níjar (Almería, España). Revista de la Sociedad Geológica de España, 3, 65-77.

Stokesbury, K.D.E. \& Himmelman, J.H. 1993. Spatial distribution of the giant scallop Placopecten magellanicus 
in unharvested beds in the Baie des Chaleurs, Québec. Marine Ecology Progress Series, 95, 159-168.

Tremblay, I., Samson-Dô, M. \& Guderley, H.E. 2015. When behavior and mechanics meet: scallop swimming capacities and their hinge ligament. Journal of Shellfish Research, 34, 203-212; doi: 10.2983/035.034.0201.

Wang, S., Duncan, P.F., Knibb, W. \& Degnan, B.M. 2001. Successful hatchery production and the first report of byssal attachment in the 'unusual' scallop, Amusium balloti. 13th International Pectinid Workshop, Coquimbo, Chile, 71-72.

Wissak, M., López-Correa, M., Gofas, S., Salas, C., Taviani, M., Jakobsen, J. \& Freiwald, A. 2009. Shell architecture, element composition, and stable isotope signature of the giant deep-sea oyster Neopycnodonte zibrowii sp. nov. from the NE Atlantic. Deep-Sea Research I, 56, 374-407; doi: 10.1016/j.dsr.2008.10.002.
Yesares-García, J. \& Aguirre, J. 2004. Quantitative taphonomic analysis and taphofacies in lower Pliocene temperate carbonate-siliciclastic mixed platform deposits (Almeria-Nijar Basin, SE Spain). Palaeogeography, Palaeoclimatology, Palaeoecology, 207, 83-103; doi: 10.1016/j.palaeo.2004.02.002.

Yonge, C.M. 1936. The evolution of the swimming habit in the Lamellibranchia. Mémoires du Musée Royal d'Histoire Naturelle de Belgique (2me series), 3, 77-100.

Young, P.C. \& Martin, R.B. 1989. The scallop fisheries of Australia and their management. CRC Critical Reviews in Aquatic Sciences, 1, 615-638.

Young, P.C., Martin, R.B., McLoughlin, R.J. \& West, G. 1990. Variability in spatfall and recruitment of commercial scallops (Pecten fumatus) in Bass Strait. In: Proceedings of the Australasian scallop workshop (eds Dredge, M.C.L., Zacharin, W.F. \& Joll, L.M.). Hobart, Australia, 80-91. 
